\title{
Drivers and Barriers for a Circular Economy (CE) Implementation in Poland-A Case Study of Raw Materials Recovery Sector
}

\author{
Marzena Smol ${ }^{1, *(\mathbb{D})}$, Paulina Marcinek ${ }^{2}(\mathbb{D})$ and Eugeniusz Koda $^{3}(\mathbb{D}$ \\ 1 Faculty of Management, AGH University of Science and Technology, Antoniego Gramatyka 10 Str., \\ 30-067 Cracow, Poland \\ 2 Mineral and Energy Economy Research Institute, Polish Academy of Sciences, Wybickiego 7a Str., \\ 31-261 Cracow, Poland; marcinek@meeri.pl \\ 3 Institute of Civil Engineering, Warsaw University of Life Sciences-SGGW, Nowoursynowska 159 Str., \\ 02-776 Warsaw, Poland; eugeniusz_koda@sggw.edu.pl \\ * Correspondence: smol@meeri.pl; Tel.: +48-12-617-16-60
}

Citation: Smol, M.; Marcinek, P.;

Koda, E. Drivers and Barriers for a Circular Economy (CE)

Implementation in Poland-A Case Study of Raw Materials Recovery

Sector. Energies 2021, 14, 2219.

https://doi.org/10.3390/en14082219

Academic Editor: Patrycja Hąbek

Received: 21 March 2021

Accepted: 15 April 2021

Published: 16 April 2021

Publisher's Note: MDPI stays neutral with regard to jurisdictional claims in published maps and institutional affiliations.

Copyright: (C) 2021 by the authors Licensee MDPI, Basel, Switzerland. This article is an open access article distributed under the terms and conditions of the Creative Commons Attribution (CC BY) license (https:// creativecommons.org/licenses/by/ $4.0 /)$.

\begin{abstract}
Mobilizing industry and transforming industrial sectors to a circular economy (CE) is one of the key areas of activities in the European Green Deal (EGD)—the newest strategy of economic growth in European Union (EU). In the $\mathrm{CE}$, the raw materials that can be recovered from various waste streams play a key role, therefore, recommendations for their management were developed, both at the European and national level. In Poland, the raw material recovery sector is one of the strategic sectors (key industries) described in several documents determining the further directions of economic growth in the country. This paper presents the revision of these documents and guidelines for the implementation of the CE in the raw material recovery sector. The scope of the paper also includes a description of the current state of the raw materials recovery sector and its return, supported by the analysis of drivers and barriers in its further development. In previous years, a dynamic development of the recovery industry was observed, followed by formation of new companies (dominated by medium-sized companies comprising $~ 50 \%$ of entities in the sector) and increasing amount of people employed ( 70,700 people). A growing level of processing of secondary raw materials with the use of more and more innovative technologies has been observed, which could contribute to the improvement of the level of innovation of the national economy. There also some barriers, such as the lack of sufficiently developed industrial symbiosis (IS) and long-term support for the implementation of recovery technologies. The growing ecological awareness of society and enterprises themselves, as well as the growing belief in the importance of resource recovery for environmental protection, suggest the possibility of subsequent development of the raw materials recovery sector. Further actions in this field will be taken to strengthen the implementation of the CE in the country.
\end{abstract}

Keywords: sustainable development; green deal; circular economy; raw materials; recovery

\section{Introduction}

In 2019, the European Commission (EC) adopted the new growth strategy for the European Union (EU) and its citizens; the European Green Deal (EGD) [1]. It aims to transform the EU society into a fair and prosperous one, living in a modern, resourceefficient and competitive economy, and to achieve zero net greenhouse gas emissions by 2050. The main message of this strategy is to ensure that economic growth is independent of the use of natural resources [2]. It is worth noting that the EGD is an integral part of the EC's strategy to implement the 2030 Agenda of the United Nations and the sustainable development goals (SDGs) and their associated targets [3]. The achievement of the EGD should be supported by the implementation of the sustainable development (SD) principles 
in the whole economy, in which production and consumption patterns and use of all natural resources, including air, land, rivers, lakes, aquifers, oceans and seas, are sustainable [3]. In summary, the objective of the EGD is to make the EU's economy sustainable [1].

One of the key activity areas in the EGD is to mobilize industry and transform an industrial sector and all of the value chain to a clean and circular economy (CE) [1]. The $\mathrm{CE}$ is defined by the EC as a "system that keeps the added value in products for as long as possible and eliminates waste" [4], a "system where the value of products, materials and resources is maintained in the economy for as long as possible, and the generation of waste minimized" [5] and as "a regenerative growth model that gives back to the planet more than it takes, advance towards keeping its resource consumption within planetary boundaries, and therefore strive to reduce its consumption footprint and double its circular material use rate in the coming decade" [6]. In all the above definitions of the CE, the raw materials that can be recovered from various waste streams play a key role; therefore, the core of the CE model should be sustainable resource management. Currently, raw materials are crucial to the European economy due to providing a strong industrial base and producing a broad range of goods and applications used in modern technologies and everyday life. However, the security of raw materials in the EU and in the world is not certain [7] due to the limited access to mineral deposits in individual regions of the world [8]. In order to secure reliable and unhindered access to certain raw materials on the European level, in 2011 the EC has created a list of critical raw materials (CRMs) for the EU, which is subject to a regular review and update. The list is updated every 3 years [9-12] and the last list of CRMs was published in 2020. The fourth list includes 30 CRMs which combine raw materials of high importance to the EU economy and have a high risk associated with their supply. The new list of CRMs aims to foster efficient usage and recycling of the CRMs, a priority area in the CE Action Plan. Moreover, it should increase awareness of potential raw material supply risks and related opportunities among EU countries, companies and investors. The EC strongly underlined that the potential for a more circular usage of CRMs in the European economy is needed [13]. The transformation toward the CE model in the raw materials sector should include each step of the value chain from production to consumption, reuse, repair and remanufacturing, waste management [14], and secondary raw materials [15] that are turned back into the economy [5].

The transformation towards the CE is a response to the environmental crisis [16,17], depletion of natural resources $[18,19]$ and continued dependence on imports of strategic raw materials from third countries [20,21]. It is a long-term process that requires legal [22], organizational and social changes, not only at the EU level but also at the national level [23]. The individual countries have prepared their plans for implementing the CE at a national level, and these are systematically published on the website of a European Circular Economy Stakeholder Platform [24]. In all developed roadmaps and strategies, the greatest attention is paid to the management of raw materials and waste. In Poland, the "Roadmap towards the Transition to Circular Economy" was adopted by the government in 2019 [25]. The Polish roadmap was indicated as one of the strategic projects of the Strategy for Responsible Development [26] and, therefore, it fits into the overall vision of the development of country. The Polish roadmap aims to identify, in particular, actions aimed at maximizing the added value of raw materials (defined as resources), materials and products, while reducing the generation of waste and maintaining the efficiency of the production and consumption processes [25]. It touches upon various aspects of the functioning of the industrial production, services and consumption sector. The transition to the CE model creates new development opportunities for the Polish raw material recovery sector, which has developed very quickly in recent years, in terms of both an increase in sales and an increase in the level of employment [27]. This is related not only to changes in regulations at the European and national level which habe promoted the CE model [28], but also an increasingly pro-ecological attitude of society [29]. In such a market, the greatest added value comes from the ability to optimally process, recover and reuse valuable waste fractions [30-32]. The objective of the paper is to identify drivers and barriers in the further 
development of the Polish raw material recovery sector. The scope of the paper includes the identification of the recommended directions for the raw materials recovery in the strategic documents and regulations in Poland; diagnosis of the current state of the sector and its return; identification of solutions that may contribute to the further dynamic development of the Polish material recovery sector and SWOT analysis (strengths, weaknesses, opportunities and threats) of sector development opportunities and discussion.

\section{Materials and Methods}

The research was divided into four three individual steps. The framework of the research is presented in Figure 1.

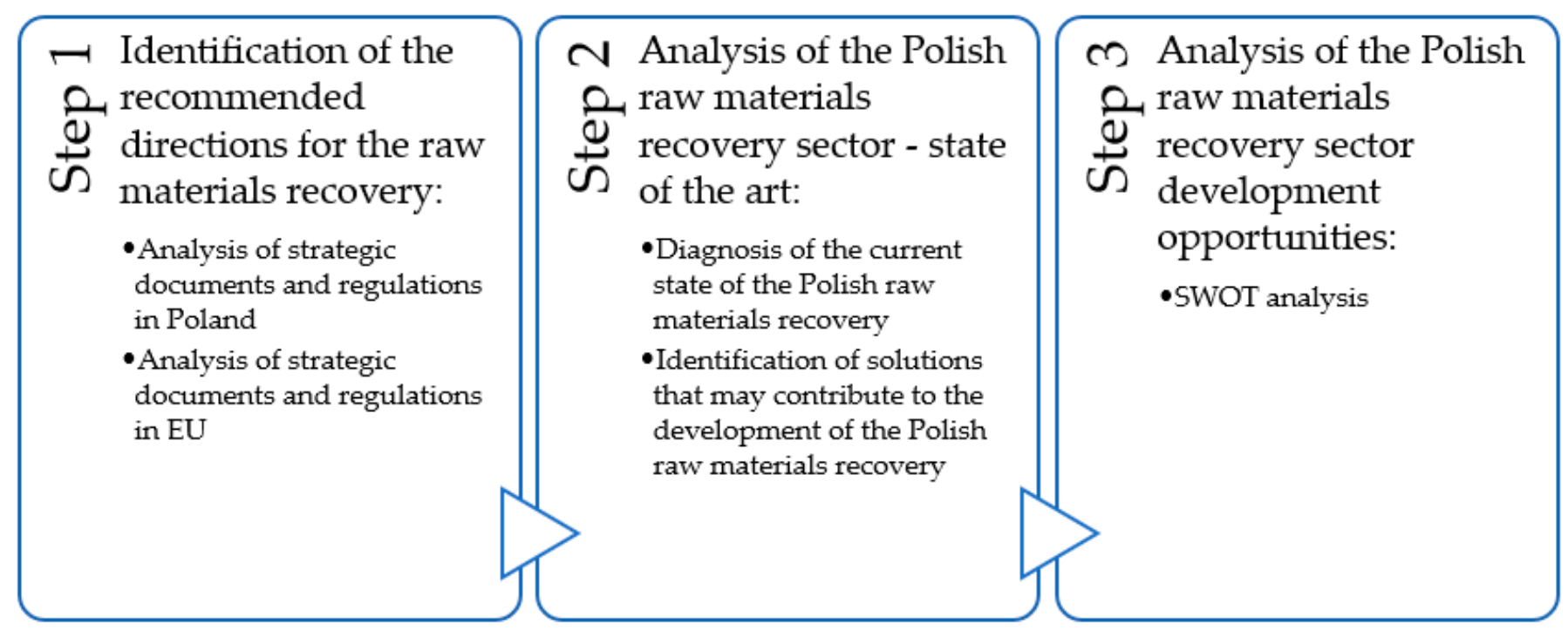

Figure 1. Research framework.

In each step of the research, the following methods were used:

Step 1: Identification of the recommended directions for the raw materials recovery in the strategic documents and regulations in Poland. In this step, a desk research method was used. It included the detailed inventory and analysis of the Polish strategic documents and the restrictions regarding waste management and raw materials recovery. The strategic documents were available for free on the official webpages of the Polish government, as the Ministry of Economic Development (which is the main responsible body in the country for the development of recommendations in the area of the CE model implementation in all industries) and the Ministry of Climate and Environment (which is responsible for the development of recommendations and actions for the CE and EGD in the context of counteracting climate change and environmental protection). The law restrictions are available for free in the official portal-the Polish Internet System of Legal Acts/ISAP (isap.sejm.gov.pl, accessed on 15 April 2021). Due to some national laws being linked to the implementation of EU laws, some of the analyzed documents originate from the official websites of the EC (ec.europa.eu, accessed on 15 April 2021) and EUR-Lex, an online database of EU laws (eur-lex.europa.eu, accessed on 15 April 2021), which is also available for free.

Step 2: Analysis of the Polish raw materials recovery, including the diagnosis of the current state of the Polish raw materials recovery and identification of solutions that may contribute to its development. The detailed analysis of the state of the art in this area was conducted with the use of a desk research method. It focused on an inventory and analysis of the documents (papers, reports) related to waste management and raw materials recovery. The analyzed papers included reviewed articles published in scientific national and international databases, such as BazTech, Polish Scientific Bibliography, Elsevier Scopus, Elsevier Science Direct, Multidisciplinary Digital Publishing Institute (MDPI) 
and Google Scholar. The analyzed reports included the reports published by the Polish entities operating in the area of the raw materials sector, the waste sector and conducting analyses of the activities of domestic enterprises, including the Polish Agency for Enterprise Development and the Statistics Poland.

Step 3: Analysis of sector development opportunities was conducted with the use of SWOT analysis, which includes the identification of four aspects of the development of raw materials recovery sector in Poland - strengths, weaknesses, opportunities and threats. This step was conducted to identify internal (strengths and weaknesses) and external factors (opportunities and threats) that are favorable and unfavorable to the further development of the raw materials recovery sector in Poland. The internal factors include strengths and weaknesses, and external factors-opportunities and threats.

\section{Results}

This section provides the results of the conducted research.

\subsection{Recommended Directions for the Raw Materials Management}

On the international level, the recovery of raw materials is underlined in the most important document, "Transforming our world: 2030 Agenda for Sustainable Development" [3], which is the complex plan of actions for people, the planet and for prosperity, grouped into 17 Sustainable Development Goals and 169 targets. The key aspect of the raw materials is the recommendation to sustainably manage natural resources, which is in the line with the $\mathrm{CE}$ assumptions. On the European level, the pathway to sustainability involves building the $\mathrm{CE}$ model in all areas of economic activity. The $\mathrm{CE}$ was introduced at the European level in the first communication of the EC in 2014 "Towards a circular economy: A zero waste programme for Europe" [4]. In 2015, the first CE Action Plan was presented in the communication "Closing the loop-An EU action plan for the Circular Economy" [5] while in 2018, the first CE indicators were proposed in the "Monitoring framework for the circular economy" [33]. In 2020, the second CE Action Plan for the EU was introduced, "A new Circular Economy Action Plan For a cleaner and more competitive Europe" [6]. The inventory of the EU documents regarding the usage of raw materials in the $C E$ is presented in Figure 2.

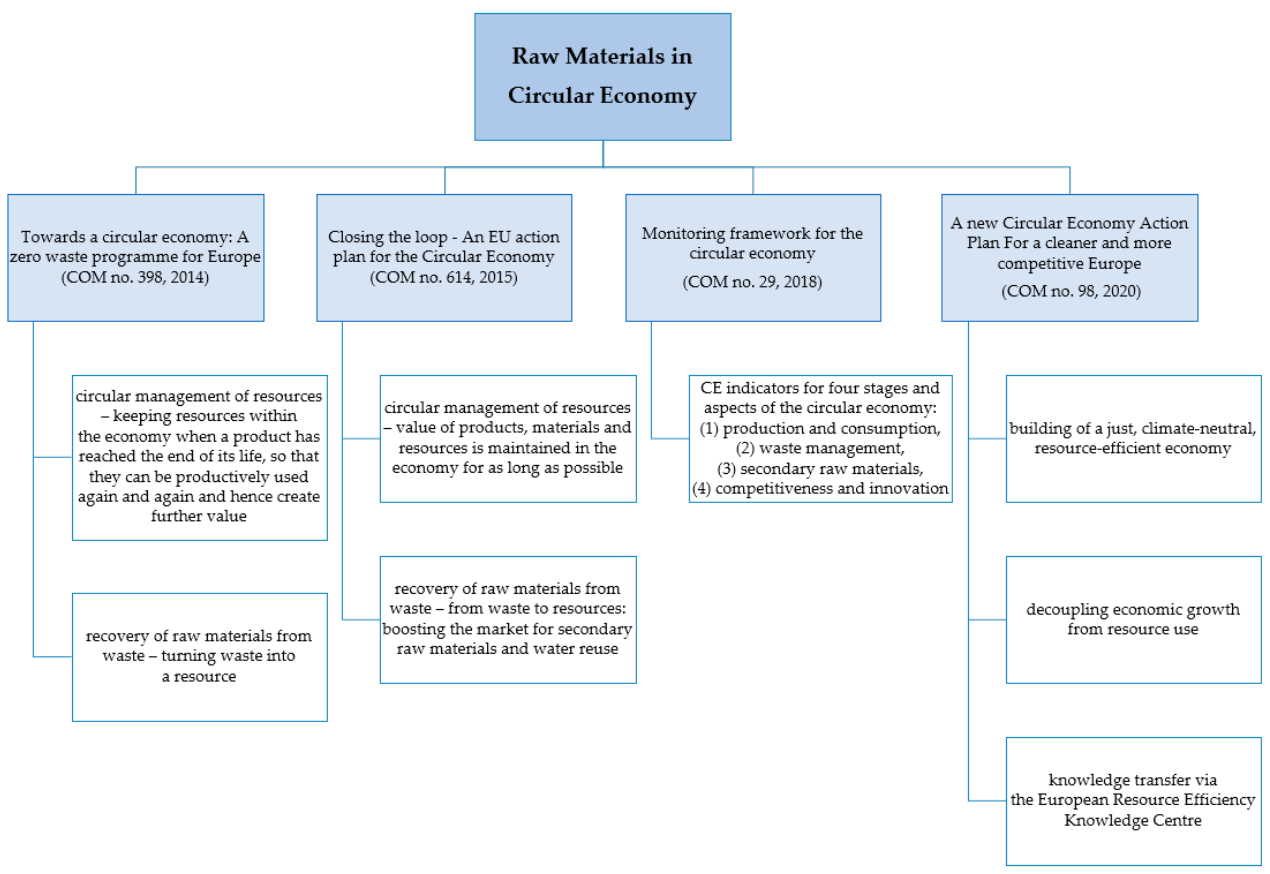

Figure 2. Inventory of the key EU documents on the CE implementation. Source: own based on $[4-6,33]$. 
Since publication, specific documents have been developed for individual sectors as the part of the CE implementation. The first one was the proposal for the CE fertilizer sector in 2016 [34]. All mentioned documents clearly underline that acting to recover raw materials and thus securing their supply to various industries is crucial for Europe, which is struggling with a shortage of many raw materials, indicated as critical. Moreover, in 2019, the EC established new strategy for economic growth which should be independent from the consumption of raw materials; the European Green Deal. Currently, the CE is one of the main blocks of the EGD, which is a strategy of economic development for all European countries, therefore, Poland has undertaken a number of activities in this area. The current analysis does not concern legal acts, as each sector of the economy has to adapt to the specific industry regulations. The most important document in the field of waste management is the Act on waste [35], which introduces EU restrictions in the Polish legal system. Another legal act that allows for the extraction of raw materials from waste is the R10 recovery regulation [36], which indicates which groups of waste can be directed to the recovery processes. However, the recovery of raw materials from waste and all technical requirements regarding the quality of secondary raw materials are regulated in legal acts dedicated to specific industries, e.g., the possibility of using recovered phosphorus (which is the critical raw material for the European economy and key raw material for the Polish economy) is regulated in legal acts on fertilizers and fertilizing.

In Poland, the Ministry of Economic Development coordinates the implementation of the CE concept. In 2016, it established the CE Working Group with representatives of various ministries, enterprises, research and education units and citizens, to develop the first CE action plan for Poland. In 2019, the Council of Ministers adopted a resolution on the adoption of the Roadmap towards the Transition to Circular Economy [25]. This document is one of the strategic projects of the Strategy for Responsible Development adopted by the Council of Ministers in 2017 [37]; this strategy underlines the importance of the raw materials. Moreover, the material recovery sector in Poland is indicated in the list of strategic sectors (key industries), based on the Strategy for Responsible Development. As a consequence of climate change and increasing demand, natural resources are becoming more scarce; therefore, further actions to protect the supply of raw materials in country are needed, not only from the perspective of environmental protection but also as a safeguard for the proper functioning of various industries. In this context, an important aspect is also the development of new business models for the CE. In the CE roadmap, the four key areas are indicated: sustainable industrial production, sustainable consumption, bioeconomy and new business models. The main objective of the CE roadmap is to secure the supply of the raw materials in the national economy. It is directly connected with the depletion of non-renewable raw materials, their rising prices and country's growing dependence on their supplies from abroad. It creates the risks related to securing a continuous supply of raw materials, especially for production industries which are the main source of gross domestic product (GDP). There also some concerns related to the challenges in the context of environmental protection (as biogenic raw materials are lost throughout the life cycle and affect, for example, eutrophication of water reservoirs, including the Baltic Sea). The circular management of raw materials and their recovery from industrial and municipal waste is indicated as the recommended direction. It is planned that the ministry responsible for the environment, in cooperation with the ministry responsible for the economy, jointly conduct the revision of regulations concerning several aspects of the industrial production, such as packaging, used electrical and electronic equipment, end-of-life vehicles, tires, batteries, accumulators, as well as lubricating oils and preparations. These organizations will also be responsible for the development of proposals for changes in the national regulations to adapt them to the EU law and their orientation to stimulate the transfer to the CE model. The recovery organizations are indicated here as important actors in the area of sustainable industrial production. In the area of bioeconomy, the recommended actions include an analysis of possible changes in the tax system and should focus more on the competitiveness of companies operating on the basis of CE business models. The 
proposed analysis should be a base for the further changes in regulatory proposals and incentives for economic activities such as recovery of key raw materials, product reuse, repair services, sharing (movables, real estate, transport production tools), rental, product quality improvement [25]. The CE Roadmap indicates that the innovative technologies in the area of waste management and raw materials recovery could play a strategic role in the transformation towards the CE model. In 2019, the Ministry of Development decided to create the National Intelligent Specialization dedicated to the CE "Circular economywater, fossil raw materials, waste". It focused on the development of preferential areas of support for research, development and innovation (R\&D\&I) in the transformation towards the $\mathrm{CE}$ in the country. Special attention is given to sustainable management of waste to keep the raw materials in the economy as long as possible [29].

In 2018, the Ministry of Environment presented the draft of the Raw Material Policy. The final document is a set of overarching principles and activities aimed at reducing the risks in the supply of raw materials aimed at securing the state's long-term economic and social needs, resulting from the adopted priorities of economic development [38]. The expected effect of these actions under this policy is to minimize the amount of generated waste and to maximize the recovery of raw materials from secondary sources (implementation of the $\mathrm{CE}$ assumptions). In the process of shaping the raw materials policy, attention should be paid to the development of technology used in the entire resource management chainfrom exploration, identification and documentation of deposits, through access, extraction, processing and recovery, to the disposal and utilization of waste and reclamation.

The newest document on raw materials management and recovery is the Industrial Policy of Poland, which is currently being finalized by the government. It is a program targeted at industrial sectors and will complement the Productivity Strategy with its sectoral approach. As part of the new Industrial Policy, problems and barriers of individual industries will be defined, and specific solutions using legislative and institutional instruments will be proposed. The draft of the proposal underlines that the industry, apart from agriculture and services, is one of the three traditionally distinguished sectors of the economy. In Poland, the largest part is industrial processing, which includes processing raw materials into products. Poland is a relatively highly industrialized country. Sector shares in the value added in the country in 2019 amounted to $18.9 \%$ compared to the value for the entire EU of $15.5 \%$. The added value in the industrial sector has been growing since 2015 (in permanent prices) by an average of $3.9 \%$ per year [39]. The main recommendation in the Industrial Policy of Poland, in the area of raw materials management, is the implementation of the $\mathrm{CE}$ assumptions, mainly through maximizing the use of resources that end up in the economic cycle. In this context, an important role is played by the new business models changing the model of selling products to selling services and ensuring industrial symbiosis (IS), in which waste generated by one unit is raw material in another unit). The CE requires eco-design of products to reduce the consumption of resources as part of production processes, design with the possibility of repair, expansion with new functions in mind, or easier to recover materials after the end of the use of the product.

In summary, the main European and national documents regarding the $\mathrm{CE}$ implementation strongly underline the sustainable management of the raw materials throughout their whole life cycle. It is important to keep the added value of products as long as possible, and if waste is generated, to recover raw materials from it. Recovery of raw materials from waste is a key element in the implementation of the CE model at the national and European levels.

\subsection{Polish Raw Materials Recovery Sector}

In Poland, the activity in the raw material recovery sector includes two approaches: (i) waste management, which is defined as the activity related to the collection, treatment and disposal of waste, and (ii) recovery of raw materials [40]. In the official documents, the recovery of raw materials is indicated as "waste collection, treatment and disposal activities; materials recovery". Moreover, the Polish Classification of Activities-PKD 
2007 [41], which is based on NACE-the Statistical Classification of Economic Activities in the European Community, classifies the raw material recovery sector in Poland (PKD 38.3) under two segments [27]:

(i) disassembly of used products (PKD 38.31), including disassembly of all types of end-of-life products and devices (cars, ships, computers, TV sets and other products) for the purpose of recovery of raw materials (PKD 38.31Z);

(ii) recovery of raw materials from segregated materials (PKD 38.32), including the processing of metal and non-metal waste into secondary raw materials through a mechanical or chemical processing process; separation and sorting of recyclable raw materials derived from non-hazardous waste or the separation and sorting into various categories of various raw materials, such as paper, plastics, beverage cans, metal, suitable for processing or recovery (PKD 38.32Z). According to Polish law, the end product of waste management can either be destined for landfill or become an output for another production process.

Waste management is an integral part of the raw materials recovery sector. In Poland, the statistics collected in Poland each year have detailed data on waste generated in the country [42]. Data are prepared in accordance with the Act on waste [35] and in accordance with the waste catalog [43], dividing waste into groups, subgroups and types according to the source of their generation. The catalog includes approximately 950 types of waste classified in 20 groups. In 2019, almost 127 million Mg of waste was generated, of which $10.1 \%$ was municipal waste (12.8 million $\mathrm{Mg}$ ). The largest amount is non-municipal waste, which amounted 114.1 million Mg. The amount of waste generated annually remains at a similar level, with a constant growth of the GDP, which may indicate positive trends in waste management. The main source of waste in 2019, as in previous years, were mining and quarrying (55.8\% of generated waste in total), industrial processing (23.8\%) as well as electricity, gas, steam and hot water production and supply $(12.3 \%)$. The structure of the industrial waste generated is shown in Figure 3. The largest share in the amount of waste generated was waste generated during the search, extraction, physical and chemical processing of ores and other minerals $(60 \%)$ and waste from thermal processes $(20 \%)$ [42].

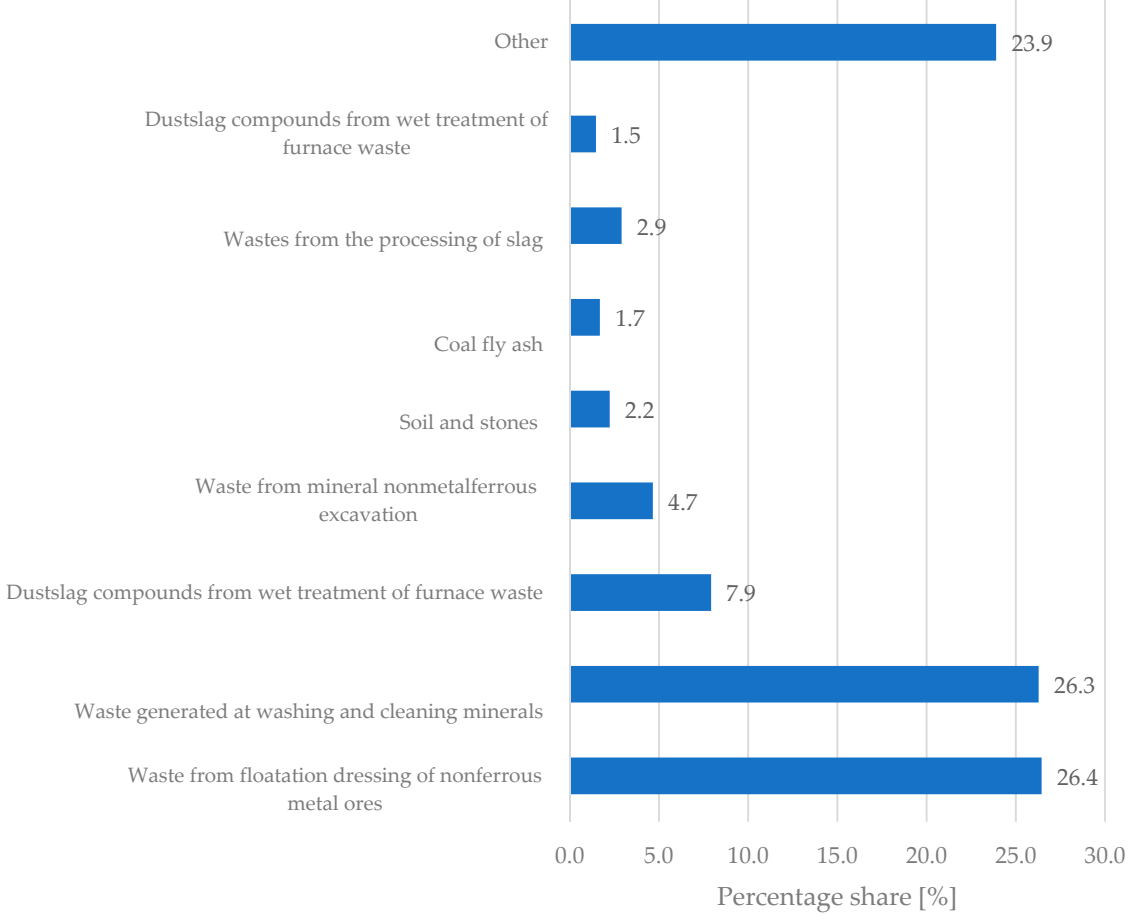

Figure 3. Structure of waste (excluding municipal waste) generated in Poland in 2019. Source: own based on [42]. 
In recent years, more and more of the waste generated is directed to recovery processes (48.9\% of generated waste in 2019). Despite the introduction of a five-step hierarchy of waste management [44] in Polish law, a large part of waste from economic activity is still landfilled (42.9\% of generated waste in 2019). The amount of waste disposed amounted to approximately 49 million $\mathrm{Mg}$ and occupied a total area of over 8 thousand ha. The largest landfill areas are in the provinces where the greatest amounts of waste are generated (Dolnośląskie, Ślasskie, Małopolskie and Łódzkie provinces). In 2019, only 1.0 ha of the area $(0.01 \%$ of the existing storage areas) had been reclaimed. In Poland, out of the total amount of waste generated in 2019,49\% of waste was recovered, $43 \%$ was disposed of by landfill, and $5 \%$ were otherwise disposed of [42].

In the case of municipal waste, in 2019, 12,753 thousand $\mathrm{Mg}$ was reported and it showed an increase in its production by $2.1 \%$ compared to the previous year. There was an increase in the amount of municipal waste generated per one inhabitant from $325 \mathrm{~kg}$ in 2018 to $332 \mathrm{~kg}$ in 2019 [42], however, it was still much lower than the EU average (489 kg per inhabitant) [45]. In total, 7.1 million $\mathrm{Mg}$ of municipal waste collected was allocated to recovery (56\% of municipal waste generated), of which 3.2 million $\mathrm{Mg}$ were intended for recycling (25\%), 2.7 million $\mathrm{Mg}$ for thermal transformation with energy recovery (22\%), 1.2 million $\mathrm{Mg}$ for biological processing (composting or digestion, 9\%). Approximately 5.7 million $\mathrm{Mg}$ was directed to the neutralization processes, of which 5.5 million $\mathrm{Mg}$ (43\% of municipal waste generated) was designated for landfill and the remaining 0.2 million $\mathrm{Mg}$ (about $1 \%$ of production) for disposal by incineration without energy recovery. Most of the municipal waste generated in 2019 (85\%, 10,776 thousand Mg) was collected from households. To direct waste to recycling processes, it is necessary to achieve the highest possible rates of selectively collected waste. Therefore, it is important to implement the legal solutions and build a selective system collection by municipal authorities and the involvement of residents in the segregation of waste generated in households. In 2019, there were 2190 public separate collection points for municipal waste, of which $37 \%$ were located in cities and $63 \%$ in rural areas. The separate collection is becoming more and more popular-almost 4 million $\mathrm{Mg}$ in 2019 (31\% of total municipal waste generated)-an increase of $10 \%$ compared to the previous year. Selective collection differs depending on the region; in 2019, $115 \mathrm{~kg}$ per capita were selectively collected in cities, and $86 \mathrm{~kg}$ per capita in rural areas.

Selectively collected waste, both in industrial and municipal activities, is the basis for the possibility of further recovery of resources. The increasing amount of selectively collected waste has a positive effect on the development of the material recovery sector. In materials management, raw materials and recycled materials are becoming more and more important. Many mineral (e.g., metals) and organic (e.g., rubber, wood, paper) materials return to production as secondary raw materials. The use of waste for the recovery of secondary raw materials (both from production processes and also from purchasing) is becoming more and more important for ecological and economic reasons. The secondary raw materials (coming from waste) that are materials resulting from the processing (mechanical or chemical processing) of production waste, pre-sorted municipal waste or scrap and used products, are suitable for direct use in the industrial production processes (replacing primary raw material) [46].

In Poland, the recovery of secondary raw materials (both from production processes and from purchasing) applies, inter alia, to steel scrap and waste, non-ferrous metals (copper, brass and bronze, aluminum, lead, zinc and tin). Extracting metals from waste materials is less energy-intensive than from primary sources. Metal recovery is largely based on end-of-life vehicles, waste batteries and accumulators, waste electrical and electronic equipment, and municipal waste. In 2019, the total revenue (jointly in production and commercial units) of metallic waste accounted for $55.8 \%$, and non-metallic waste $44.2 \%$. The structure of total revenue for metallic waste was dominated by purchase, which amounted to $71.2 \%$, followed by revenue from own activity-23.0\%. The smallest share in total revenue of metallic waste was that of import $(5.8 \%)$. The structure for total revenue 
of non-metallic waste was similar, with the largest part being purchase $(61.3 \%)$, then the income from own activity $(34.0 \%)$ and import (4.7\%). There were no significant changes compared to the previous year [46].

The changes in the amount of economic entities operating in the raw materials recovery sector is presented in Figure 4. In total, in 2018, 4512 entities, including 305 public and 4207 private, operated in the Polish raw material recovery sector. The sector is dominated by medium-sized companies (employing 50-249 employees), which constitute almost 50\% of the total number of economic entities in the sector, and employing a total of 70,700 people, which is approx. $2.2 \%$ of all employees in the industry. The number of people employed in this sector is growing very dynamically, as in previous years it was 57.4 thousand in 2010, 64,400 in 2016, and 69,200 thousand in 2017. In recent years, the average monthly gross salary in the sector has systematically increased, however, it is $15 \%$ lower than the average monthly gross salary in industry as a whole in the country. Of the three main sections in this sector, the highest salaries are provided in materials recovery, compared to waste treatment and disposal and waste collection. In addition, compared to the energy sector, the labor costs per paid employee (monthly averages) was approximately $50 \%$ lower. Despite this fact, there is an upward trend observed in employment in the sector. Moreover, the coronavirus pandemic did not affect this trend and it has consistently grown [40]. The prediction showed that in the next 5 years, the increase in the demand for employees will amount to no less than 2000 people per year, meaning that the industry will have to compete strongly for employees with other industries, and possibly also with other sectors of the economy [27]. It is likely to take over at least some of the employees who lose their jobs in declining industries. However, some of the newly employed will be graduates of secondary and higher education institutions and people previously working outside the industry.

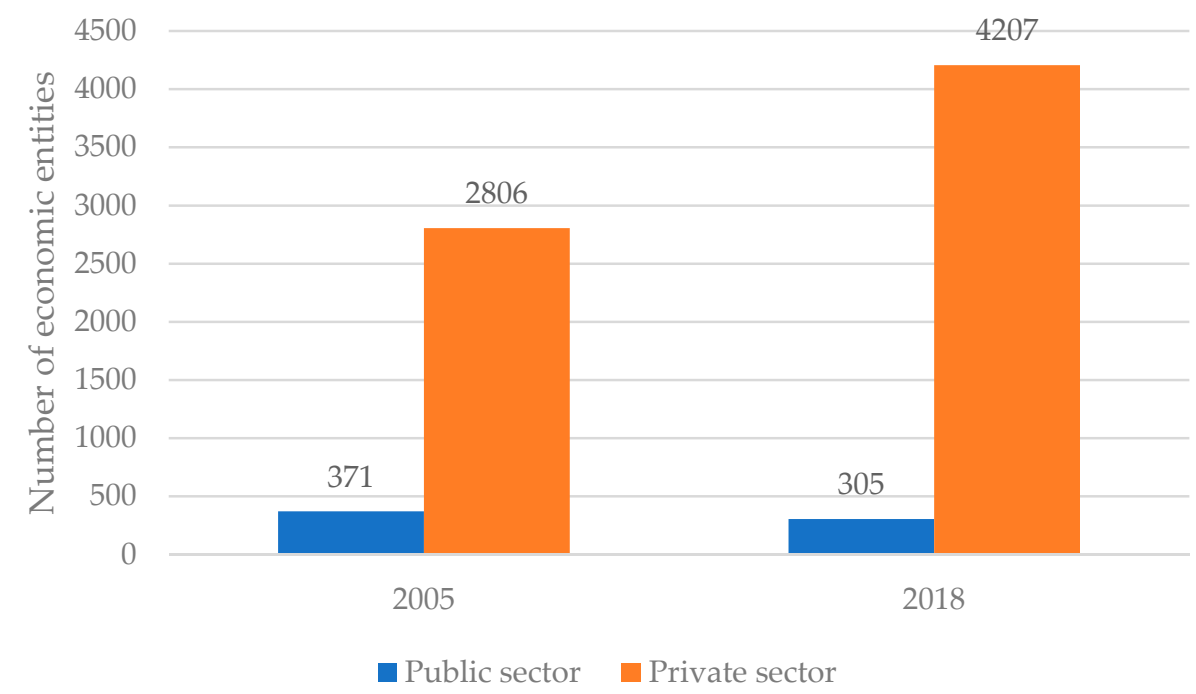

Figure 4. Economic entities operating in the raw materials recovery sector in Poland in 2005-2018. Source: own based on [40].

The basic data on the economic entities in the raw material recovery sector in Poland in 2018 is provided in Table 1. The number of entities conducting activity in 2018 reached 1062 , of which the smallest number were companies with $\geq 40.01$ million EUR of sold production. At the same time, those companies achieved the highest sold production values, reaching 1993.2 million EUR. The total sold production in all operating companies in 2018 reached 3890.2 million EUR. The value of the sector's global production in 2018 amounted to approx. 5.8 billion EUR, while in 2015 it reached 4.4 billion EUR. Mediumsized enterprises employing 50 to 249 employees in this sector achieved total revenues of 1946.9 million EUR, and smaller companies employing 49 or fewer people-912.7 million EUR [27]. 
Table 1. Basic data regarding economic entities in the raw material recovery sector in Poland in 2018 (in absolute numbers).

\begin{tabular}{|c|c|c|c|c|c|c|c|}
\hline \multirow{2}{*}{ Specification } & \multirow{2}{*}{ Total } & \multicolumn{6}{|c|}{ Entities by Value of Sold Production in Million EUR * } \\
\hline & & $\leq \mathbf{2 . 0 0}$ & $2.01-5.00$ & $5.01-10.00$ & $10.01-20.00$ & $20.01-40.00$ & $\geq 40.01$ \\
\hline $\begin{array}{l}\text { Number of entities } \\
\text { conducting activity } \\
\text { during the year }\end{array}$ & 1062 & 153 & 289 & 221 & 179 & 125 & 95 \\
\hline $\begin{array}{l}\text { Sold production in } \\
\text { million EUR * }\end{array}$ & 3890.2 & 37.8 & 205.3 & 355.3 & 543.7 & 754.9 & 1993.2 \\
\hline $\begin{array}{l}\text { Average paid } \\
\text { employment in } \\
\text { thousands }\end{array}$ & 59.1 & 2.3 & 5.5 & 7.3 & 10.1 & 12.8 & 21.1 \\
\hline
\end{tabular}

* 1 EUR $=4.6$ PLN, based on the average exchange rates provided by the Polish National Bank, March 2021. Source: own based on [40].

An important trend in the development of Polish enterprises has also been the introduction of new or improved products or business processes in 2016-2018. Approximately $23.6 \%$ of the total companies operating in this period introduced such processes. In 2018, approximately 15.2 million EUR was spent on innovation activities in the Polish companies operating in the raw materials recovery sector. In total, $15.6 \%$ of this expenditure was directed to research and development activity (intramural and extramural expenditures), $50.7 \%$ - capital on tangible and intangible assets, and $0.6 \%$ - own personnel working on innovation. Source of funds on innovation activities mainly came from own sources of enterprises (31.3 million EUR) [40].

It is expected that in the coming years, waste management in Poland will continue to change $[47,48]$. The main factors in this area are regulatory trends in the EU, promoting the CE model and the EGD [1]. In such a market, the greatest added value will come from the ability to optimally process, recover and reuse valuable fractions of waste, rather than a simple process of collecting and depositing waste in landfills. The value and importance of the raw material recovery sector has constantly increased, which could also result in a greater share of enterprises generating GDP and a greater number of jobs in the raw material recovery sector.

\subsection{Drivers and Barriers in the Development of the Raw Material Recovery Sector}

The transformation towards the circular economy is a response to the environmental crisis, depletion of natural resources and continued dependence on imports of the strategic raw materials from third countries. The implementation of the CE model could create new opportunities for the Polish raw material recovery sector. However, there are also some barriers to the further development of the sector. The results of the SWOT analysis showing the internal factors (strengths and weaknesses) and external factors (opportunities and threats) of the further development of the raw materials recovery sector in Poland are presented in Table 2.

Table 2. SWOT analysis of the raw materials recovery sector in Poland.

\begin{tabular}{|c|c|}
\hline SWOT Element & Description \\
\hline & High importance of the sector in the national economy: \\
\hline STRENGTHS & $\begin{array}{l}\text { - } \quad \text { sector indicated as strategic (key industry) in the Strategy for Responsible Development; } \\
\text { sector included in the National Intelligent Specialization dedicated to the CE "Circular } \\
\text { economy-water, fossil raw materials, waste"; } \\
\text { underlining the raw materials recovery as the key element of the CE implementation in Polis } \\
\text { CE roadmap; } \\
\text { - }\end{array}$ \\
\hline
\end{tabular}


Table 2. Cont.

Dynamic development of the recovery industry and the formation of new companies:

- $\quad$ increase in revenues for the country from the activity of the sector;

- $\quad$ positive effect on employment growth (an opportunity for socially and professionally excluded people);

- $\quad$ maintaining the high quality of products after the recycling process comparable to products obtained from primary raw materials;

- $\quad$ well-developed cooperation network of Polish companies (including high and small and medium-sized enterprises-SME) dealing with the recycling of raw materials (e.g., the Waste Management and Recycling Cluster);

- $\quad$ an increase in the implementation of research and development projects $(R \& D)$ in the field of new technologies of raw material recovery and waste management.

Impact on innovation and competitiveness of national economy:

- development of innovative technologies for the recovery of raw materials;

- use of modern technologies in the waste recycling sector in order to maintain/increase competitiveness, improve work safety and reduce the environmental impact;

- $\quad$ growing level of processing of secondary raw materials with the use of more and more innovative processing technologies and recycling, which contributes to the improvement of the level of innovation in the Polish economy;

- $\quad$ high capacity and variety of production for the country and for export.

Impact on the environment and society:

- the use of secondary raw materials associated with the reduction of energy consumption in technological processes in many industries;

- $\quad$ the use of waste materials affects the minimization or elimination of landfilled waste;

- increasing ecological awareness of enterprises operating in the industry, manifested by, e.g., in the preparation of reports and corporate social responsibility strategies.

Imperfections of science-business cooperation:

- lack of staff with knowledge in the field of substitution and recycling of raw materials;

- $\quad$ insufficient transfer and exchange of experience between scientists and business

WEAKNESSES

- $\quad$ lack of sufficient knowledge and experience in running R\&D projects in many enterprises;

- lack of experience in commercialization of the research results by the research units;

- $\quad$ underfunded research infrastructure of national research and development units;

- $\quad$ implementation of economically unprofitable ventures and R\&D projects.

Impact on the financial resources of enterprises:

- $\quad$ high capital expenditure in the area of technological facilities required for the processing and recovery of certain types of waste;

- $\quad$ insufficient funds for conducting R\&D projects and development investments in enterprises;

- $\quad$ possibility of failure of R\&D projects with high financial outlays from enterprises.

Market barriers:

- lack of sufficiently developed industrial symbiosis between entities that could participate in the exchange of waste/recyclable materials;

- $\quad$ grey zone (market) activity (e.g., collection points carrying out illegal disassembly of used equipment without permits and without the need to meet a number of requirements and standards).

Technological barriers:

- lack of sufficient infrastructure for recovery of individual raw materials;

- lack of inventory of adequate technologies;

- lack of qualified technical staff.

Further development of policy and recommendations for the recovery of raw materials:

OPPORTUNITIES

- $\quad$ finalizing the Raw Material Policy;

- $\quad$ adjusting legal instruments stimulating cooperation between science and business;

- development of legal instruments stimulating building the industrial symbiosis. 
Table 2. Cont.

Further implementation of recommended actions in strategic national and international documents:

- $\quad$ intensify the recovery of raw materials from waste to reduce the scale of exploitation from primary sources as a key direction in the Raw Material Policy, including, e.g.:

$\bigcirc$ use of mining, ashes and slags as well as other waste in road construction;

$\bigcirc \quad$ management of synthetic gypsum resulting from flue gas desulphurization;

$\bigcirc \quad$ implementation of a system for collecting and processing waste electrical and electronic equipment as well as batteries and accumulators;

$\bigcirc$ use in the management of waste obtained from waste landfills, mining waste neutralization facilities or waste dumps and their processing in recovery processes; $\bigcirc$ unifying the rules of separate collection of municipal waste throughout the country

- implementation of recommended actions in the CE roadmap;

- $\quad$ reducing the fiscal burden for companies implementing and using recycled products.

Development of tools supporting the development of the market for secondary raw materials:

- development of economic instruments stimulating cooperation between science and business (e.g., under Horizon Europe and European Institute of Innovation \& Technology-EIT Raw Materials);

- $\quad$ modernization of the Waste Database (BDO) in order to obtain any functionality of the system and organize the database;

- development of economic instruments (EU subsidies and low-interest loans) for investments promoting the development of waste management and environmental protection (e.g., National Fund for Environmental Protection and Water Management; Polish Agency for Enterprise Development);

- development of a system for the selection and storage of waste from which it may be possible to recover raw materials in the future;

- $\quad$ access to technology and scientific achievements thanks to the increased participation of the $\mathrm{R} \& \mathrm{D}$ sector in foreign research projects;

- $\quad$ access to new technologies, machines and devices through building the network of infrastructures in the country and abroad;

- $\quad$ implementation of procedures provided for a given sector of the economy to avoid legal chaos and possible consequences resulting from actions taken individually to protect employees.

Social and environmental drivers:

- $\quad$ increasing environmental awareness and culture;

- $\quad$ changes in the consumer behavior and preferences (increased interest in recycled products);

- $\quad$ large and absorbent market for eco-products from waste recycling and secondary raw materials (domestic and export).

Technological perspectives:

- $\quad$ large resources of unused secondary raw materials, including strategic metals and rare earth elements important for the development of many sectors of the national and global economy (protection of natural resources);

- development of material technologies.

Lack of sufficient law instruments:

- $\quad$ lack of finalized and implemented the Raw Material Policy;

- $\quad$ focusing in regions and central policy mainly on municipal waste management, not industrial waste in the region;

- frequently changing legal regulations in the field of recycling and waste management

- $\quad$ lack of clear instruments to encourage actions and investments in the field of recycling and waste management;

THREATS

- insufficient number of legal and organizational solutions to limit the activities of the shadow economy in the waste recycling industry;

- $\quad$ excessive level of bureaucracy and requirements for entrepreneurs;

- administrative delays in issuing decisions resulting from the coronavirus pandemic and other factors. 
Table 2. Cont.

\begin{tabular}{|c|c|}
\hline SWOT Element & Description \\
\hline & $\begin{array}{l}\text { Market barriers: } \\
\text { - } \quad \text { an underdeveloped market for secondary raw materials; } \\
\text { - high interest and competition of large, innovative foreign companies in obtaining and } \\
\text { recycling waste and their potential entry into the Polish market; } \\
\text { - further export of untreated waste-with the existing insufficient processing capacity in the } \\
\text { country; } \\
\text { short life span of new technologies (quick expiration of solutions and innovations) with } \\
\text { relatively high capital intensity. }\end{array}$ \\
\hline & $\begin{array}{l}\text { Social concerns: } \\
\text { - low public awareness of the importance of minerals in the economy and reluctance to } \\
\text { change behavior; } \\
\text { - lack of confidence in the quality of products from waste for individual consumers. }\end{array}$ \\
\hline
\end{tabular}

The raw material recovery sector is one of the strategic sectors (key industries) in Poland [27,49], indicated in the several documents determining further directions of economic growth in the country [50]. In recent years, the dynamic development of the recovery industry has been observed [51,52], supporting the formation of new companies [46]. The increasing number of enterprises operating in this sector positively affects the number of people employed; the current unemployment in Poland is equal to 6.5\% [53]. The coronavirus pandemic has had no significant impact on employment in the raw materials recovery sector, but is unsurprisingly and significantly affecting the number of people working in other industries [27], which in the future may also have consequences for the raw materials industry. The situation is quite uncertain due to the lack of information on the real development of companies supported by the government (in the form of tax credits, exemptions from contributions, non-returnable grants and loans on preferential terms) as measures to counteract the effects of a pandemic [54]. It can be assumed that the coronavirus pandemic in the coming years may also have negative consequences for the raw material recovery sector, but at the moment, they are not identifiable.

The important aspect of the sector is maintaining the high quality of products after the recycling process, comparable to products obtained from primary raw materials. Products from waste must meet specific requirements in order to be placed on the market (depending on the specific requirements of a given sector/product) [35]. More and more companies and scientists deal with the development of products that meet certain quality requirements [55-59], which in the context of potential commercialization may lead to an increase in the recognition of Polish solutions and products on European and world markets. There are also many concerns about the waste that has been in contact with people infected with coronavirus (including municipal and medical waste). The Polish Chief Sanitary Inspectorate has published guidelines for dealing with waste generated during the coronavirus epidemic. They contain recommendations, among other things, for which bin to throw in and how to protect used face masks, gloves and other personal protective equipment. However, in practice, these principles are not fully adhered to. Municipal waste from an infected person should be placed in a bag intended for this purpose, and then the bag should not be sprayed with a disinfectant; this waste should be collected selectively. In the case of collection of waste from quarantine facilities or municipal rubbish bins, the guidelines of the Minister of Climate and Environment, and the Chief Sanitary Inspector apply. Waste produced by healthy people (even those in quarantine), such as preventive measures (masks, gloves) used at work, public transport, during shopping, should be thrown into a mixed (residual) waste container or bag, i.e., a garbage can in black bags. Medical waste produced in hospitals is considered hazardous. They are placed in red bags and disposed of by specialized plants.

In previous years, an evolution of cooperation in the sector was also observed [60]. Currently, there is a well-developed cooperation network of companies (including high 
and small and medium-sized enterprises; SME) in the Waste Management and Recycling Cluster. It aims to increase competitiveness, the effectiveness of using possessed resources and the exchange of knowledge. It is indicated as the key cluster for the Polish economy and it offers the possibility of implementing innovative products onto the market by the companies belonging to the cluster. It is also more and more involved in international collaboration, e.g., by participation in research and development projects (R\&D) in the field of new technologies of raw material recovery and waste management (under European Institute of Innovation \& Technology; EIT Raw Materials). The raw materials recovery sector has had a significant impact on the innovation (including eco-innovations) [61,62] and competitiveness of the national economy through the development and implementation of innovative technologies for waste management [63-65] and recovery of raw materials $[66,67]$. A growing level of processing of secondary raw materials with the use of more and more innovative processing technologies has been observed [68], which could contribute to the improvement of the level of innovation in the Polish economy [69], although the existing processing capacity of the infrastructure in this scope should be assessed as insufficient.

The sector also has an impact on the environment and society [70]. The use of secondary raw materials is associated with the reduction of energy consumption in technological processes in many industries [71], especially if they are also able to use renewable energy sources in the recovery processes [72]. Moreover, the use of waste materials affects the minimization or elimination of landfill waste [73], which can protect against leachate generation and contamination of groundwater. The promotion of waste-based products also helps to shape the ecological awareness of society [74], which has significantly increased in recent years [75]. There is also a positive trend in the number of reports and corporate social responsibility (CSR) strategies prepared by individual enterprises operating in the industry [76-78]. The companies and education units (educating on raw materials management and recovery) present themselves as socially and environmentally responsible [79], building a positive image and consumer confidence [80]. This growing interest in social and environmental motives of entrepreneurship is mainly caused by economic, social and political changes in last year's [81].

As a consequence of the recommendations regarding the CE implementation in official national and European documents, the raw materials recovery sector has further development opportunities because it is supported by the vision of economic growth of the countries and the EU. In the coming years, it is expected to intensify the recovery of resources from waste to reduce the scale of exploitation from primary sources and reduction of dependence on external markets [82], especially those politically risky areas such as Russia, China and the United States. There is also a strong need for the further legal instruments to support CE implementation. One of these could be legal (and economic) incentives stimulating building the industrial symbiosis [83]. Many enterprises show some concern to build the IS due to the lack of support from local and central authorities and legal barriers [84]. Introducing legal instruments and economic incentives would help to establish new collaborations in the context of "my waste-your raw materials". There are also economic opportunities to support the development of enterprises operating in the industry, resulting from the new EU financial perspective for 2021-2027, such as Horizon Europe with 100 billion EUR (including EIT Raw Materials) [2] or national support instruments (e.g., National Fund for Environmental Protection and Water Management; Polish Agency for Enterprise Development) [27]. Poland belongs to the Regional Innovation Scheme (RIS) countries, to which the EU allocates additional funds to stimulate their development and to reduce the differences in innovation between highly developed countries, such as Sweden, Netherlands or Germany. It is worth taking advantage of these funds, especially as they are and (and will be) available under the EIT RMs-focused on cooperation along the entire raw material value chain.

There are also several weaknesses of the sector's activity and limitations of its further development. Despite the quite well-developed cooperation between science and business, 
the real needs of business and scientists are still different [85]. Scientists focus on solving a scientific problem, not necessarily taking into account the economic aspects, while in real market conditions, only cost-effective solutions are able to survive and bring the assumed income. Moreover, the jointly conducted R\&D projects often encounter other communication and legal problems, especially at the stage of commercialization. The closer collaboration (building trust and relationship) and knowledge exchange should therefore be strengthened [86] through industrial internships for researchers. Moreover, the interesting instruments which are gaining more and more popularity are so-called "implementation doctorates" [87], which require close cooperation between PhD students, business mentors and scientific mentors to develop a solution that has a scientific value with a business case at the same time.

There is also a strong need to solve the problem of grey zone (market) activity, which includes several collection points carrying out illegal disassembly of used equipment without permits and without the need to meet a number of requirements and standards. The gray zone also covers the difficult-to-control practices of getting rid of the selected troublesome waste (i.e., plastics, tires and others) through fires at temporary storage sites. The government intervention at the central and local level should be increased in this scope, e.g., by increasing environmental penalties (fees) and thus discouraging non-compliance with the law on the waste market. The Polish key stakeholders in the raw materials recovery sector should integrate the efforts to support the further development of the sector, especially as foreign investors are very interested in entering the domestic market.

\section{Conclusions}

In recent years, the dynamic development of the raw materials recovery sector in Poland has been observed. Mainly, it is a consequence of the implementation of the recommended actions in the European and national documents regarding the $\mathrm{CE}$ implementation. These documents strongly underline that due to environmental crisis and limited access to raw materials in Europe (especially those indicated on the CRMs list), the sustainable management of the raw materials throughout their whole life cycle is a priority. In this context, one of the most important aspects of the raw materials recovery sector is sustainable waste management that allows for the recovery of secondary resources from waste generated in various branches of the economy (industrial and municipal). Therefore, striving for a zero waste approach is recommended as an integral part of the transformation process towards the CE. The implementation of the zero waste approach, which is observed in the past few years, aims to reduce waste and increase recovery of raw materials. On the national level, it has contributed to an increase in the level of processing of waste, and recovery of secondary raw materials, with the use of more and more innovative technologies. In the following years, it could contribute to the improvement of the level of innovation of the national economy.

The sector is developing dynamically, with the formation of new companies and an increasing amount of people being employed. However, there are also some barriers to its further development, such as a lack of sufficiently developed industrial symbiosis and a lack of long-term support for the implementation of recovery technologies. Moreover, there is also a strong need to solve the problem of the grey zone through greater government intervention.

In the coming years, the proposition of tools supporting the development of the market for secondary raw materials, followed by law and economic instruments and closer collaboration between science and business, are needed. The value of the sector is expected to increase in the coming years, both in terms of GDP and the number of people employed. Therefore, further actions to strengthen the implementation of the CE in the country will be conducted both by the authorities and key stakeholders in the raw materials recovery sector-scientists and entrepreneurs. 
Author Contributions: Conceptualization, M.S. and E.K.; methodology, M.S.; formal analysis, M.S.; investigation, M.S., E.K. and P.M.; resources, M.S., E.K. and P.M.; data curation, M.S. and P.M.; writing—original draft preparation, M.S.; writing—review and editing, M.S.; visualization, M.S. All authors have read and agreed to the published version of the manuscript.

Funding: This research was funded by the Polish National Agency for Academic Exchange (NAWA) as the part of the project Monitoring of water and sewage management in the context of the implementation of the circular economy assumptions (MonGOS) within the International Academic Partnerships Programme (2020-2022), project no. PPI/APM/2019/1/00015/U/00001/ZU/00002. Part of the research was founded under the Subvention of the Division of Biogenic Raw Materials in MEERI PAS.

Institutional Review Board Statement: Not applicable.

Informed Consent Statement: Not applicable.

Data Availability Statement: The datasets generated during and/or analyzed during the current study are available from the corresponding author on reasonable request.

Conflicts of Interest: The authors declare no conflict of interest. The founders had no role in the design of the study; in the collection, analysis, or interpretation of data; in the writing of the manuscript, or in the decision to publish the results.

\section{References}

1. European Commission Communication from the Commission: The European Green Deal; European Commission: Brussel, Belgium, 2019.

2. Smol, M.; Marcinek, P.; Duda, J.; Szołdrowska, D. Importance of sustainable mineral resource management in implementing the circular economy (CE) model and the european green deal strategy. Resources 2020, 9, 55. [CrossRef]

3. United Nations Resolution adopted by the General Assembly on 25 September 2015. Transforming our world: The 2030 Agenda for Sustainable Development. Int. J. Mar. Coast. Law 2015, A/RES/70/1. [CrossRef]

4. European Commission Communication from the Commission-Towards a Circular Economy: A Zero Waste Programme for Europe; European Commission: Brussel, Belgium, 2014.

5. European Commission Communication from the Commission. Closing the Loop-An EU Action Plan for the Circular Economy; European Commission: Brussel, Belgium, 2015.

6. European Commission Communication from the Commission. Circular Economy Action Plan for a Cleaner and More Competitive Europe; European Commission: Brussel, Belgium, 2020.

7. Blengini, G.A.; Nuss, P.; Dewulf, J.; Nita, V.; Talens Peiró, L.; Vidal-Legaz, B.; Latunussa, C.; Mancini, L.; Blagoeva, D.; Pennington, D.; et al. EU methodology for critical raw materials assessment: Policy needs and proposed solutions for incremental improvements. Resour. Policy 2017, 53, 12-19. [CrossRef]

8. Mancini, L.; Benini, L.; Sala, S. Characterization of raw materials based on supply risk indicators for Europe. Int. J. Life Cycle Assess. 2018, 23, 726-738. [CrossRef]

9. European Commission Communication from the Commission: On the Review of the List of Critical Raw Materials for the EU and the Implementation of the Raw Materials Initiative; European Commission: Brussel, Belgium, 2014.

10. European Commission Communication from the Commission to the European Parliament, the Council, the Eurpean Economic and Social Committee and the Committee of the Regions on the 2017 List of Critical Raw Materials for the EU; European Commission: Brussel, Belgium, 2017.

11. European Commission Critical Raw Materials Resilience: Charting a Path towards Greater Security and Sustainability; European Commission: Brussel, Belgium, 2020.

12. European Commission Tackling the Challenges in Commodity Markets and on Raw Materials; European Commission: Brussel, Belgium, 2011.

13. European Commission Report on Critical Raw Materials and the Circular Economy; European Commission: Brussel, Belgium, 2018.

14. Godlewska, J. Recovery and Recycling of Waste Tires in Poland. Procedia Eng. 2017, 182, 229-234. [CrossRef]

15. Smol, M. The importance of sustainable phosphorus management in the circular economy (CE) model: The Polish case study. J. Mater. Cycles Waste Manag. 2019, 21, 227-238. [CrossRef]

16. Zaleski, P.; Chawla, Y. Circular economy in Poland: Profitability analysis for two methods of waste processing in small municipalities. Energies 2020, 13, 5166. [CrossRef]

17. Hobson, K.; Lynch, N. Diversifying and de-growing the circular economy: Radical social transformation in a resource-scarce world. Futures 2016, 82, 15-25. [CrossRef]

18. Kostygova, L. Prospects for implementing a circular economy in industry based on territorial innovative clusters. Int. Multidiscip. Sci. GeoConf. Surv. Geol. Min. Ecol. Manag. SGEM 2018, 18, 631-638.

19. Martins, F.F.; Castro, H. Raw material depletion and scenario assessment in European Union-A circular economy approach. Energy Rep. 2020, 6, 417-422. [CrossRef] 
20. Di Maio, F.; Rem, P.C.; Baldé, K.; Polder, M. Measuring resource efficiency and circular economy: A market value approach. Resour. Conserv. Recycl. 2017, 122, 163-171. [CrossRef]

21. Mehr, J.; Jedelhauser, M.; Binder, C.R. Transition of the Swiss phosphorus system towards a circular economy-part 1: Current state and historical developments. Sustainability 2018, 10, 1479. [CrossRef]

22. Wilts, H.; von Gries, N.; Bahn-Walkowiak, B. From waste management to resource efficiency-the need for policy mixes. Sustainabillity 2016, 8, 622. [CrossRef]

23. Smol, M.; Adam, C.; Preisner, M. Circular economy model framework in the European water and wastewater sector. J. Mater. Cycles Waste Manag. 2020, 22, 682-697. [CrossRef]

24. ECESP Strategies. European Circulare Economy Stakeholder Platform. 2021. Available online: circulareconomy.europa.eu/ platform (accessed on 9 March 2021).

25. Roadmap Transformation towards a Circular Economy; Ministry of Economic Development: Warsaw, Poland, 2019.

26. Graczyk, A. Social, economic and territorial cohesion and the development of energy sector in Strategy for Responsible Development. Optim. Econ. Stud. 2017, 90, 206-213. [CrossRef]

27. Identification of Support Instruments for the Development of the Automotive Sector-Industry Report; Polish Agency for Enterprise Development, Institute for Labour Market Analyses: Warsaw, Poland, 2020.

28. Hartley, K.; van Santen, R.; Kirchherr, J. Policies for transitioning towards a circular economy: Expectations from the European Union (EU). Resour. Conserv. Recycl. 2020, 155, 104634. [CrossRef]

29. Smol, M.; Duda, J.; Czaplicka-Kotas, A.; Szołdrowska, D. Transformation towards circular economy (CE) in municipal waste management system: Model solutions for Poland. Sustainability 2020, 12, 456. [CrossRef]

30. Iacovidou, E.; Velis, C.A.; Purnell, P.; Zwirner, O.; Brown, A.; Hahladakis, J.; Millward-Hopkins, J.; Williams, P.T. Metrics for optimising the multi-dimensional value of resources recovered from waste in a circular economy: A critical review. J. Clean. Prod. 2017, 166, 910-938. [CrossRef]

31. Dróżdż, D.; Wystalska, K.; Malińska, K.; Grosser, A.; Grobelak, A.; Kacprzak, M. Management of poultry manure in PolandCurrent state and future perspectives. J. Environ. Manag. 2020, 264. [CrossRef]

32. Bień, J.D.; Bień, B. Utilisation of Municipal Sewage Sludge By Thermal Methods in the Face of Storage Disallowing. Inżynieria Ekol. 2015, 45, 36-43. [CrossRef]

33. European Commission A Monitoring Framework for the Circular Economy; European Commission: Brussel, Belgium, 2018.

34. European Commission Proposal for a Regulation on the Making Available on the Market of CE Marked Fertilising Products and Amending Regulations (EC) No 1069/2009 and (EC) No 1107/2009 Annexes 1 to 5. 2016. Available online: https: / / eur-lex. europa.eu/legal-content/EN/TXT/?uri=CELEX\%3A52016PC0157 (accessed on 15 March 2021).

35. Act of 14 December 2012 on Waste; Ministry of the Environment: Warsaw, Poland, 2012.

36. Regulation of the Minister of the Environment of January 20, 2015 Regarding the R10 Recovery Process; Ministry of the Environment: Warsaw, Poland, 2015.

37. Ministry of Economic Development Strategy for Responsible Development for the Period Up to 2020 (Including the Perspective Up to 2030); Ministry of Environment: Warsaw, Poland, 2017.

38. Draft of the Raw Material Policy (PSP); Ministry of Environment: Warsaw, Poland, 2018.

39. Ministry of Economic Development Labour and Technology Polish Industrial Policy-Statement; Ministry of Environment: Warsaw, Poland, 2021.

40. Statistical Yearbook of Industry-Poland; Statistics Poland: Warsaw, Poland, 2020.

41. Regulation on Polish Classification of Activities (PKD); Council of Ministers: Warsaw, Poland, 2007.

42. Environment 2020; Statistics Poland: Warsaw, Poland, 2020.

43. Regulation of the Minister of the Environment, Republic of Poland, Catalogue of Waste; 2nd of January; Ministry of the Environment: Warsaw, Poland, 2020.

44. European Union Directive 2018/851 amending Directive 2008/98/EC on waste Framework. Off. J. Eur. Union 2018, 30, 44.

45. European Commission Eurostat. 2020. Available online: ec.europa.eu/eurostat (accessed on 9 March 2021).

46. Materials management in 2019; Statistics Poland: Warsaw, Poland, 2020.

47. Generowicz, A.; Gaska, K.; Hajduga, G. Multi-criteria Analysis of the Waste Management System in a Metropolitan Area. E3S Web Conf. 2018, 44, 1-8. [CrossRef]

48. Vaverkova, M.; Adamcova, D.; Winkler, J.; Koda, E.; Petrzelova, L.; Maxianova, A. Alternative method of composting on a reclaimed municipal waste landfill in accordance with the circular economy: Benefits and risks. Sci. Total Environ. 2020, 723, 137971. [CrossRef] [PubMed]

49. Jarosiński, A.; Zelazny, S.; Cholewa, M. Raw materials and possibilities of their obtaining in Poland. Inz. Miner. 2016, 17, 233-240.

50. Rosiek, K. Directions and challenges in the management of municipal sewage sludge in Poland in the context of the circular economy. Sustainability 2020, 12, 3686. [CrossRef]

51. Pietrzyk, S.; Tora, B. Processing of non-ferrous metals secondary raw materials in Poland-Trends, opportunities and threats. Inz. Miner. 2017, 2, 81-92.

52. Tomaszewska, J. Polish transition towards circular economy: Materials management and implications for the construction sector. Materials 2020, 13, 5228. [CrossRef] 
53. Statista Registered unemployment rate during the coronavirus (COVID-19) epidemic in Poland from 2020 to 2021.2021. Available online: www.statista.com/statistics/1112606/poland-unemployment-rate-during-covid-19-pandemic (accessed on 9 March 2021).

54. Gajdzik, B.; Wolniak, R. Influence of the covid-19 crisis on steel production in poland compared to the financial crisis of 2009 and to boom periods in the market. Resources 2021, 10, 4. [CrossRef]

55. Cesaro, A.; Belgiorno, V.; Guida, M. Compost from organic solid waste: Quality assessment and European regulations for its sustainable use. Resour. Conserv. Recycl. 2015, 94, 72-79. [CrossRef]

56. Hicks, C.; Dietmar, R.; Eugster, M. The recycling and disposal of electrical and electronic waste in China-Legislative and market responses. Environ. Impact Assess. Rev. 2005, 25, 459-471. [CrossRef]

57. Johansson, N.; Krook, J. How to handle the policy conflict between resource circulation and hazardous substances in the use of waste?: Three countries' regulations on contaminants in waste and their implications for resource circulation. J. Ind. Ecol. 2021, 1-15. [CrossRef]

58. Schoch, K.; Liedtke, C.; Bienge, K. Designing on the basis of recycling-metallurgy possibilities: Material-specific rules and standards for "anti-dissipative" products. Resources 2021, 10, 5. [CrossRef]

59. Smol, M.; Adam, C.; Kugler, S.A. Thermochemical treatment of Sewage Sludge Ash (SSA)-potential and perspective in Poland. Energies 2020, 13, 5461. [CrossRef]

60. Urbaniak, M. Building relationships with suppliers in new product development processes. Stud. Ekon. Zesz. Nauk. Uniw. Ekon. Katowicach 2017, 321, 9-19.

61. Joanna, Z.; Żabińska, I.; Zaręskki, A. Eco-Innovations in Poland-the Extent of Changes, Development and Barriers. Sci. Pap. Silesian Univ. Technol. Organ. Manag. Zesz. Nauk. Politech. Sl. Ser. Organ. Zarz. 2019, 245-256. [CrossRef]

62. Panfiluk, E. Innovativeness of tourism enterprises: Example of Poland. Sustainability 2021, 13, 1024. [CrossRef]

63. Kamizela, T.; Worwag, M. Processing of Water Treatment Sludge by Bioleaching. Energies 2020, 13, 6539. [CrossRef]

64. Pyssa, J. Technical and technological aspects of sewage waste management after amendments in legislation in Poland. IOP Conf. Ser. Earth Environ. Sci. 2019, 214, 012016. [CrossRef]

65. Werle, S.; Sobek, S. Gasification of sewage sludge within a circular economy perspective: A Polish case study. Environ. Sci. Pollut. Res. 2019, 26, 35422-35432. [CrossRef]

66. Lewandowska, A.; Szymańska, D. Municipal waste recycling in big cities in Poland in the context of ecologisation. Bull. Geogr. 2019, 43, 131-141. [CrossRef]

67. Lewicka, E. Rational use of selected mining by-products in the ceramic industry in Poland. Gospod. Surowcami Miner. Miner. Resour. Manag. 2020, 36, 59-76.

68. Borowski, P.F. Innovative processes in managing an enterprise from the energy and food sector in the era of industry 4.0. Processes 2021, 9, 381. [CrossRef]

69. Żelazny, R. Determinants and measurement of smart growth: Evidence from Poland. J. Int. Stud. 2017, 10, 34-45. [CrossRef] [PubMed]

70. Oláh, J.; Aburumman, N.; Popp, J.; Khan, M.A.; Haddad, H.; Kitukutha, N. Impact of industry 4.0 on environmental sustainability. Sustainability 2020, 12, 4674. [CrossRef]

71. Szostak, E.; Duda, P.; Duda, A.; Górska, N.; Fenicki, A.; Molski, P. Characteristics of Plastic Waste Processing in the Modern Recycling Plant Operating in Poland. Energies 2020, 14, 35. [CrossRef]

72. Gródek-Szostak, Z.; Suder, M.; Kusa, R.; Szelag-Sikora, A.; Duda, J.; Niemiec, M. Renewable Energy Promotion Instruments Used by Innovation Brokers in a Technology Transfer Network. Case Study of the Enterprise Europe Network. Energies 2020, 13, 5752. [CrossRef]

73. Alwaeli, M. An overview of municipal solid waste management in Poland. The current situation, problems and challenges. Environ. Prot. Eng. 2015, 41, 181-193. [CrossRef]

74. Kaur, G.; Uisan, K.; Ong, K.L.; Ki Lin, C.S. Recent Trends in Green and Sustainable Chemistry \& Waste Valorisation: Rethinking Plastics in a circular economy. Curr. Opin. Green Sustain. Chem. 2018, 9, 30-39.

75. Bombiak, E.; Marciniuk-Kluska, A. Green Human Resource Management as a Tool for the Sustainable Development of Enterprises: Polish Young Company Experience. Sustainability 2018, 10, 1739. [CrossRef]

76. Hąbek, P. Corporate social responsibility reporting in mining sector. The European Union perspective. Sci. Pap. Silesian Univ. Technol. Organ. Manag. Ser. 2020, 2020, 159-172.

77. Habek, P.; Lechowicz, P. Assessment of sustainable production practices. The case of company from metal industry. Multidiscip. Asp. Prod. Eng. 2019, 2, 447-456. [CrossRef]

78. Koda, E.; Osiński, P. Site Investigation of an Industrial Landfill for the Purpose of a Remedial Works Project. ASCE Geotech. Spec. Publ. 2016, 750-757. [CrossRef]

79. Sady, M.; Żak, A.; Rzepka, K. The Role of Universities in Sustainability-Oriented Competencies Development: Insights from an Empirical Study on Polish Universities. Adm. Sci. 2019, 9, 62. [CrossRef]

80. Pactwa, K.; Woźniak, J. Environmental reporting policy of the mining industry leaders in Poland. Resour. Policy 2017, 53, 201-207. [CrossRef]

81. Sady, M.; Buła, P. Dual mission of startups: Defining and situating the concept. Contemp. Organ. Manag. Chall. Trends 2020, 3, 95-111. 
82. Havukainen, J.; Nguyen, M.T.; Hermann, L.; Horttanainen, M.; Mikkilä, M.; Deviatkin, I.; Linnanen, L. Potential of phosphorus recovery from sewage sludge and manure ash by thermochemical treatment. Waste Manag. 2016, 49, 221-229. [CrossRef]

83. Wanat, L.; Potkański, T.; Chudobiecki, J.; Mikołajczak, E.; Mydlarz, K. Intersectoral and intermunicipal cooperation as a tool for supporting local economic development: Prospects for the forest and wood-based sector in Poland. Forests 2018, 9, 531. [CrossRef]

84. Domenech, T.; Bleischwitz, R.; Doranova, A.; Panayotopoulos, D.; Roman, L. Mapping Industrial Symbiosis Development in Europe_typologies of networks, characteristics, performance and contribution to the Circular Economy. Resour. Conserv. Recycl. 2019, 141, 76-98. [CrossRef]

85. Wasiluk, A.; Ginevičius, R. Pro-innovative motives for establishing cooperation by enterprises: An empirical study in Poland. Econ. Sociol. 2020, 13, 258-278. [CrossRef]

86. Radomska, J.; Wołczek, P.; Sołoducho-Pelc, L.; Silva, S. The impact of trust on the approach to management-A case study of creative industries. Sustainability 2019, 11, 816. [CrossRef]

87. Kwiek, M. Poland: An Abundance of Doctoral Students but a Scarcity of Doctorates. In Trends and Issues in Doctoral Education: A Global Perspective; Sage: Thosand Oaks, CA, USA, 2019; pp. 103-126. 